\title{
Treatment of Pituitary and Other Tumours with Cabergoline: New Mechanisms and Potential Broader Applications
}

\author{
Shaojian Lin ${ }^{a, b} \quad$ Anke Zhang ${ }^{b} \quad$ Xun Zhang ${ }^{c}$ Zhe Bao Wu ${ }^{a}$ \\ ${ }^{a}$ Center of Pituitary Tumour, Department of Neurosurgery, Ruijin Hospital, Shanghai Jiao Tong University School \\ of Medicine, Shanghai, China; ${ }^{b}$ Department of Neurosurgery, Shanghai General Hospital, Shanghai Jiao Tong \\ University School of Medicine, Shanghai, China; ${ }^{C}$ Neuroendocrine Research Laboratory, Massachusetts General \\ Hospital and Harvard Medical School, Boston, MA, USA
}

\section{Keywords}

Pituitary adenomas · Cabergoline - Prolactinoma ·

Resistance mechanism

\begin{abstract}
Cabergoline is a dopamine agonist that has been used as the first-line treatment option for prolactin-secreting pituitary adenomas for several decades. It not only suppresses hormone production from these prolactinomas, but also causes tumour shrinkage. Recent studies revealed some novel mechanisms by which cabergoline suppresses tumour cell proliferation and induces cell death. In this article, we review the most recent findings in cabergoline studies, focusing on its anti-tumour function. These studies suggest the potential broader clinical use of cabergoline in the treatment of other tumours such as breast cancer, pancreatic neuroendocrine tumours, and lung cancer.

(c) 2019 S. Karger AG, Basel
\end{abstract}

\section{Introduction}

The dopamine receptor family includes D1-like and D2-like receptors. D1 and D5 receptors are members of the D1-like subfamily of receptors which couple to the G

karger@karger.com

(C) 2019 S. Karger AG, Basel

www.karger.com/nen

Karger! protein Gsa and stimulate adenylyl cyclase (AC) to produce cAMP, while D2, D3, and D4 receptors are members of the D2-like subfamily of receptors which couple to the G protein Gia and block the activity of AC. Cabergoline $(\mathrm{CAB})$ is an ergoline derivative with potent, selective, and long-lasting inhibitory activity on prolactin (PRL) secretion from lactotrophs of the anterior pituitary [1]. Compared to bromocriptine (BRC), $\mathrm{CAB}$ is more potent in binding to the D2 dopamine receptor (DRD2), which causes AC inhibition, decreases cAMP and induces apoptosis. Meanwhile, $\mathrm{CAB}$ induces autophagic cell death (ACD) by activating DRD5 [2-5]. CAB is better tolerated than BRC in the majority of patients, with fewer side effects and more convenient dosing schedules. Recently, the efficacy of CAB treatment has also been reported in patients with acromegaly, clinically non-functioning adenomas, as well as Cushing's disease (CD) [6-9]. Excellent reviews of the clinical use of $C A B$ in the treatment of prolactinomas have been published $[1,10,11]$. In this article, we will review some recent studies of the mechanisms of CAB actions and discuss its potential novel application in cancer treatment.

Zhe Bao Wu, MD, PhD

Center of Pituitary Tumour, Department of Neurosurgery, Ruijin Hospital 197\# Ruijin Er Road

Shanghai 200025 (China)

E-Mail zhebaowu@ aliyun.com

Xun Zhang, PhD

Neuroendocrine Research Laboratory

Massachusetts General Hospital and Harvard Medical School

Boston, MA 02114 (USA)

E-Mail xzhang5@mgh.harvard.edu 


\section{Mechanisms of Action}

\section{Suppression of PRL Production}

In the 1980s and 1990s, researchers studied CAB actions through pharmacodynamic and pharmacokinetic properties [10]. Several excellent reviews have been published to discuss the mechanisms for the suppression of PRL by dopamine [12-14]. Briefly, dopamine binds to DRD2, which is functionally linked to G proteins Gia, and suppresses high intrinsic secretory activity, PRL gene expression, and lactotroph proliferation. CAB strongly inhibits PRL secretion mainly through binding to DRD2. $\mathrm{DRD} 2$ is a 7-transmembrane G-protein coupled receptor associated with Gi proteins. By alternative splicing, the D2 receptor gene encodes two molecularly distinct isoforms, a short form of DR (D2S) and a long form of DR (D2L) [15]. In lactotrophs, CAB stimulation of D2S is more potent than D2L, which causes inhibition of AC, in turn, decreases intracellular cAMP concentrations and blocks IP3-dependent release of $\mathrm{Ca}^{2+}$ from intracellular stores [16]. The inhibition of cAMP is a key step in the inhibition of hormone release by dopaminergic agents [17]. Furthermore, the inhibition of PRL mRNA synthesis could be reversed using long-acting analogues of cAMP [18].

Clinical studies showed that $\mathrm{CAB}$ markedly reduced plasma PRL levels after single or multiple $0.5 \mathrm{mg} / \mathrm{kg}$ doses, and the PRL-lowering effects appeared $2-8 \mathrm{~h}$ after administration and lasted for $72 \mathrm{~h}$ or longer, in agreement with its in vivo half-life of $63-69 \mathrm{~h}$, which was determined from urinary samples of 12 healthy subjects [19]. CAB has been used as the first-line treatment option for prolactinomas $[1,10]$.

\section{Suppression of Cell Proliferation}

When used in patients with prolactinomas, CAB not only suppresses PRL secretion but also causes tumour shrinkage. Early animal studies showed that DRD2 knockout resulted in the development of prolactinomas in the pituitary gland [20], indicating the involvement of DRD2 in the control of lactotroph proliferation [21]. Furthermore, ablation of the DRD2 gene in mice leads to a sexually dimorphic phenotype of hyperprolactinemia and pituitary hyperplasia, which is stronger in females. It has been reported that activation of DRD2 resulted in apoptosis in lactotroph cells in an oestrogen-dependent manner [22]. In addition, D2S was observed to activate phospholipase D, which may be linked to its potent antiproliferative effect [23]. Subsequent studies have revealed multiple mechanisms for the anti-proliferative function of dopamine agonists (DAs) $[5,24]$.
Regulation of the Mitogen-Activated Protein Kinase/ Extracellular-Regulated Kinase Signalling Pathway

It has been shown that increased expression of D2S, but not D2L, leads to rapid phosphorylation of extracellular-regulated kinase (ERK), thus activating the mitogen-activated protein kinase (MAPK)/ERK signalling pathway $[25,26]$. In rat lactotroph MMQ cells, treatment with DA increased ERK phosphorylation, accompanied by suppression of cell proliferation; consistently, transgenic mice with increased expression of D2S in lactotrophs showed a clear increase of ERK phosphorylation and displayed lactotroph hypoplasia [25]. The rat GH3 cells lack functional DRD2. However, in GH3 cells with DRD2 expression established by stable transfection, treatment of DAs resulted in apoptosis, which was correlated with activation of p38 MAPK and ERK1/2 [27]. Furthermore, dopamine-induced cell death was abrogated by inhibitors of MAPK/MEK1/ERK signalling [27]. Similar results were observed in primary cultures of human clinically non-functioning pituitary tumour cells treated with DAs or a dopamine-somatostatin chimeric compound [28]. Taken together, these data indicate the involvement of the MAPK/ERK signalling pathway in the anti-proliferative function of $\mathrm{CAB}$.

\section{Activation of the Mammalian Target of Rapamycin}

Pathway and Autophagy

The mammalian target of rapamycin (mTOR) is a serine/threonine protein kinase belonging to the phosphatidylinositol 3-kinase (PI3K)-related family. It plays multiple roles involving gene transcription, protein synthesis, cell survival, proliferation, cell mobility, and autophagy $[29,30]$. When activated by extracellular signals, PI3K phosphorylates and activates AKT, which in turn either activates or inhibits multiple downstream targets, including mTOR, which is activated by AKT $[31,32]$. A study using dopamine receptor knockout animal models revealed that DRD2 was essential for the inhibition of Akt activity by dopamine [33]. We have recently established a direct link between DAs and mTOR-mediated ACD. In rat pituitary cell lines MMQ and GH3, CAB suppressed cell proliferation in vitro and tumour growth in vivo [24]. $\mathrm{CAB}$ treatment of these cells decreased phosphorylation of AKT and mTOR, as well as decreased phosphorylation of p70S6K and 4EBP1, two key downstream effectors of the mTOR pathway. The conversion of microtubule-associated protein light chain 3-I (LC3-I) to lipidated LC3-II is a classical hallmark of autophagy activation. In MMQ and GH3 cells, CAB treatment increased LC3-I to LC3-II conversion and induced the formation of autolysosomes, 
indicating that $\mathrm{CAB}$ activated autophagy. Consistent with this study, Geng et al. [34] recently reported that LC3 protein was present in prolactinomas from patients treated with BRC but absent in normal human pituitaries or prolactinomas from patients with no medical treatment, as determined by immunohistochemistry. Interestingly, in $\mathrm{CAB}$-treated cells, the components within autolysosomes failed to be degraded by lysosomal proteases due to the acidification of autolysosomes. Thus, CAB initiated autophagy but disrupted autophagic flux, resulting in ACD [24]. Using receptor-specific agonists and antagonists, combined with RNAi technology, Leng et al. [5] identified that DRD5 was responsible for CAB-mediated $\mathrm{ACD}$ via $\mathrm{mTOR}$ activation. Furthermore, the mechanism for mTOR activation and induction of ACD was not restricted in pituitary tumour cells. Similar results were obtained with other human cancer cells, such as colon cancer, gastric cancer, and glioblastoma cells, due to the high expression of DRD5, suggesting a potential broad therapeutic application of $\mathrm{CAB}$ in different human tumours [5].

\section{Inhibition of Angiogenesis}

Recent studies have shown that $\mathrm{CAB}$ inhibits angiogenesis. In a mouse ovarian tumour model, dopamine significantly inhibited the effect of vascular endothelial growth factor (VEGF) and suppressed tumour cell adhesion and peritoneal angiogenesis [35]. In contrast, ablation of dopaminergic nerves with a neurotoxin dramatically increased angiogenesis, microvessel density, and microvascular permeability in a mouse melanoma model, accompanied by increased type 2 VEGF receptor (VEGFR-2) phosphorylation [36]. In a model of experimentally induced endometriosis, human endometrium fragments were implanted into the peritoneum of female nude mice. After the mice were given $\mathrm{CAB}$ orally, a significant decrease was observed in the percentage of active endometriotic lesions and the cellular proliferation index Ki-67. CAB treatment significantly reduced neo-microvessel formation in this model and suppressed the expression of the pro-angiogenic factors VEGF and Notch-4 but increased the expression of the anti-angiogenic factors Ang-1 and Wnt-1, accompanied by an inhibition of VEGFR-2 phosphorylation [37]. Increased DRD2 expression has been recently reported in human lung cancer tissues as well as lung cancer cell lines; CAB treatment resulted in decreased tumour progression and angiogenesis in a murine lung cancer model [38]. Furthermore, it has been shown that $\mathrm{CAB}$ was able to inhibit VEGF protein production and secretion in human granulosa cells [39]. Many studies have shown increased angiogenesis in

New Mechanisms and Applications of Cabergoline human pituitary adenomas as well as oestrogen-induced prolactinomas in rats [40-43]. Interestingly, it has been reported that a giant invasive prolactinoma resistant to $\mathrm{CAB}$ treatment strongly expressed the angiogenic factors VEGF and FGF-2, as well as an endothelial marker CD31 [44]. Taken together, these data suggest that CAB suppression of pituitary tumour cell growth through dopamine receptor activation is at least in part by inhibition of angiogenesis.

\section{Current Clinical Use of CAB in Pituitary Tumour Treatment}

\section{Prolactinomas}

$\mathrm{CAB}$ is the first-line treatment for prolactinomas, because of its high efficacy and tolerability. CAB has been shown to be more effective in normalizing PRL levels and reducing tumour size with fewer adverse effects than BRC $[45,46]$. In a systematic review of the literature including 6 observational studies and 3 randomized trials comparing $B R C$ with $C A B$, it was concluded that BRC was less effective than $\mathrm{CAB}$ in reducing the risk of persistent hyperprolactinemia (RR, 2.88; 95\% CI, 2.20-3.74; I2 = 0\%), amenorrhoea/oligomenorrhoea (RR, 1.85; 95\% CI, 1.402.36), and galactorrhoea (RR, 3.41; 95\% CI, 1.9-5.84). Furthermore, in patients with invasive giant prolactinomas (IGPs), CAB is significantly better than BRC at normalizing PRL levels, especially in male patients (69.4 vs. $31.7 \%$ ) [47]. Huang et al. [4] recently confirmed in their retrospective study that $\mathrm{CAB}$ was an excellent option for the treatment of 15 patients with BRC-resistant IGPs.

In a retrospective study with 455 patients [48], treatment with CAB normalized serum PRL levels in $86 \%$ of the patients. Serum PRL normalization was achieved in $92 \%$ of the 244 patients with idiopathic hyperprolactinaemia or macroprolactinoma, and in $77 \%$ of the $181 \mathrm{pa}-$ tients with macroprolactinoma. Side effects were noted in $13 \%$ of patients, including nausea, headache, dizziness, and postural hypotension. However, DA therapy was discontinued only in $3.9 \%$ of patients [48]. We reviewed publications from 2000 to 2018, which included 1,362 patients, and found that treatment with $\mathrm{CAB}$ normalized serum PRL levels in $79.7 \%$ of patients. In particular, PRL normalization was found in $84.0 \%$ of the 541 patients with microprolactinomas, and in $76.9 \%$ of the 821 patients with macroprolactinoma. Tumour reduction was reported in $73.9 \%$ of patients, while the $99 \%$ shrinkage was reported in several patients, and side effects were noted only in $5.1 \%$ of patients [3,49-61] (Table 1 ).

Neuroendocrinology 2020;110:477-488 
Table 1. Overview of efficacy of cabergoline treatment in patients with prolactinoma

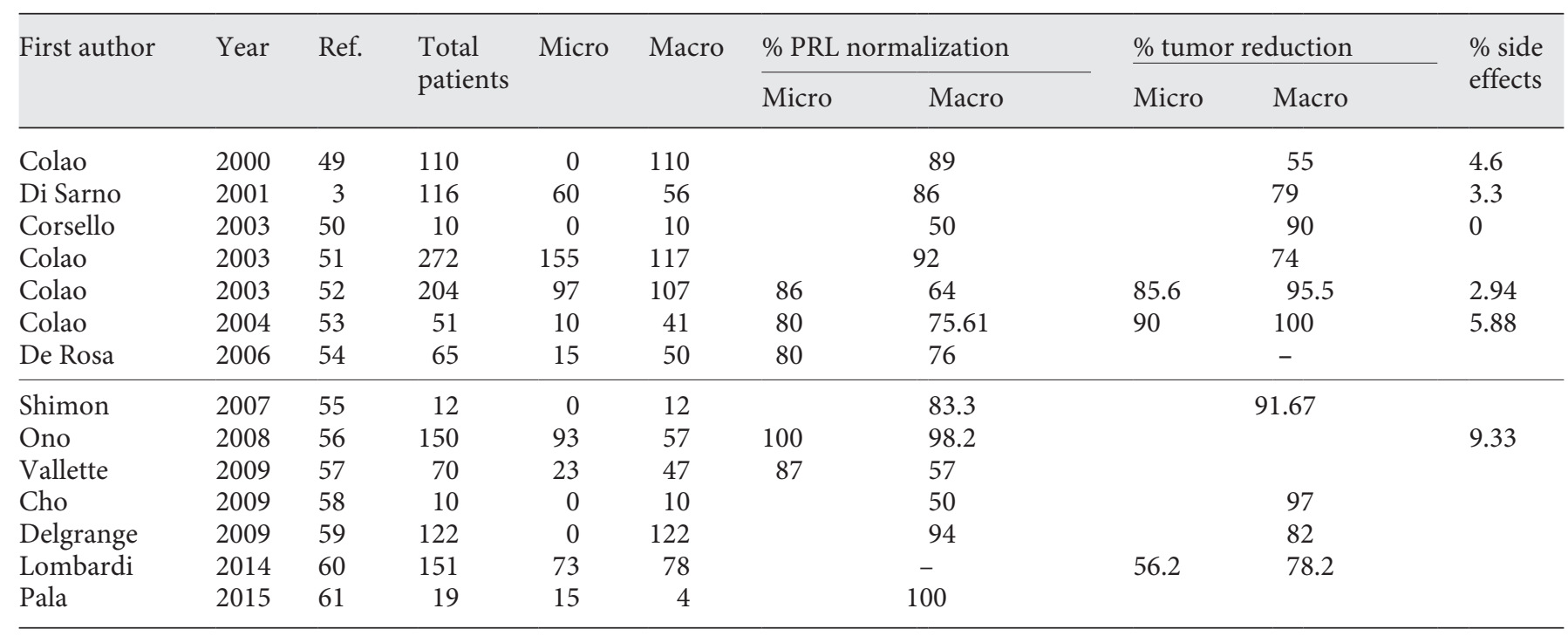

Micro, microadenoma; Macro, macroadenoma.

Giant PRL adenomas (size $\geq 40 \mathrm{~mm}$; PRL $>1,000 \mathrm{ng} /$ $\mathrm{mL}$ ) are uncommon, with reported prevalence of $2-3 \%$ of all prolactinomas and only $0.5 \%$ of all pituitary tumours [62]. Giant prolactinomas are generally benign, but they may be aggressive and invasive [63]. Recently, Shimon [64] reported that DA treatment led to normalized PRL, improved vision, and normalized testosterone in 60-68, 70 , and $40-67 \%$ of giant prolactinoma patients, respectively. Hamidi et al. [63] conducted a study in 71 giant prolactinomas that showed $58.8 \%$ complete biochemical response, $94.4 \%$ improved visual field, and $25 \%$ complete structural response after DA monotherapy (84.2\% CAB therapy) [65, 66]. Although $\mathrm{CAB}$ represents a first-line therapy effective in reducing PRL levels and determining tumour shrinkage $[63,67]$, surgery, radiation and a combination of other agents, such as temozolomide and somatostatin receptor ligands, may be needed in select cases $[68,69]$.

Resistant prolactinomas are generally defined as those in which CAB treatment fails to normalize PRL blood concentrations or reduce tumour volume above $50 \%$ at a dose of $3.5 \mathrm{mg}$ or more per week [70,71], and when there is absence of serum PRL normalization and/ or $50 \%$ tumour shrinkage after at least 3 months of treatment with BRC at a dose of $15 \mathrm{mg}$ daily [72]. Several studies have suggested that different mechanisms are associated with drug resistance, including a decreased expression of the D2S/D2L receptor [73-75], decreased expression of the Gai2 inhibitory Ga G protein subunit, which is coupled to the D2 receptor [75], antagonistic effects of oestrogen which decrease the effects of DAs and increase cell proliferation [76], and potential involvement of certain drug resistance-related genes such as PRB3 [77]. Li et al. [78] reported that the TGF- $\beta$ / Smad signalling pathway may play an important role in DA-resistant prolactinomas, and SB431542 as a TGF- $\beta 1 /$ Smad3 signalling-specific inhibitor may serve as a promising novel treatment for preventing fibrosis and further improving the drug resistance of prolactinomas [79]. Complete resistance to $\mathrm{CAB}$ is infrequent. In a study of 122 patients, Delgrange et al. [59] showed that only 7 patients $(6 \%)$ could not achieve control despite maximal $\mathrm{CAB}$ doses for $>12$ months. Ono et al. [56] reported normalization of PRL in 10 of 11 patients, with weekly doses of $\mathrm{CAB}>2 \mathrm{mg}$ /week (4 patients required $3 \mathrm{mg}$, 2 required $6 \mathrm{mg}, 4$ required $9 \mathrm{mg}$, and 1 patient required 12 $\mathrm{mg}$ ). Doses of CAB up to $21 \mathrm{mg} /$ week have been reported in some resistant cases [80]. Partial resistance to DAs can often be overcome by increasing the dose of $\mathrm{CAB}$ stepwise to maximal tolerable doses and waiting for the drug effects to increase over time, but patients must be informed of the potential long-term side effects of $\mathrm{CAB}$ at such high doses, in particular of the risk of cardiac valvular abnormalities $[81,82]$. The effect of low-dose $\mathrm{CAB}$ on cardiac valves is still controversial $[83,84]$, and requires further investigation. 


\section{Acromegaly}

More than $95 \%$ of patients with acromegaly have a growth hormone-producing pituitary adenoma [85]. The acromegaly guideline published in the Journal of Clinical Endocrinology and Metabolism in 2014 recommended transsphenoidal surgery as the primary therapy in most patients [86]. In addition, several medications, including somatostatin receptor ligands, DAs, and GH receptor antagonists such as pegvisomant (PEG), are now available if surgery fails to suppress GH/IGF-I hypersecretion. The use of PEG or CAB has also been suggested in patients with inadequate responses to somatostatin receptor ligands [86]. CAB has been used to treat acromegaly as an off-label drug since the 1990s [87, 88]. It can be used alone, or in combination with somatostatin analogues (SSAs) or PEG [87]. Dopamine binding sites on GH-secreting adenomas have been demonstrated [89], and DRD2 expression was later confirmed $[90,91]$. The rationale for the use of CAB in combination with SSAs in acromegaly is that DRD2 and type 5 somatostatin receptor (SSTR5) can heterodimerize, thus enhancing the functional activity of both agonists [90]. A previous metaanalysis of 9 trials of CAB monotherapy in a total of 149 patients showed that 48 and $34 \%$ of patients achieved a GH level below $2.5 \mathrm{ng} / \mathrm{mL}$ and a normal plasma IGF-I level, respectively $[6,92]$. Almost $40-50 \%$ of patients who were only partially responsive to SSA alone achieved normalization of IGF-I levels when CAB was added $[6,92]$. In patients who were not responsive to PEG alone at maximal doses, biochemical control can be achieved in $>50 \%$ of patients following the $\mathrm{CAB}$ and PEG combination scheme, with no significant adverse events [93]. Treatment with CAB suppressed plasma IGF-I below $300 \mathrm{ng} /$ $\mathrm{mL}$ in $39 \%$ of cases and between 300 and $450 \mathrm{ng} / \mathrm{mL}$ in another $28 \%$ of cases [87]. The pretreatment plasma IGFI levels affect the treatment effect dramatically. Thus, $\mathrm{CAB}$ is mainly recommended for patients with borderline or moderately increased plasma IGF-I levels (twice the upper level of the normal range) $[6,86]$.

\section{Clinically Non-Functioning Adenomas}

Non-functioning pituitary adenomas (NFPAs) comprise a heterogeneous group of lesions, with the majority (up to $90 \%$ ) of gonadotroph origin [94], as shown by positive staining of FSH $\beta$-, LH $\beta$-, and/or $\alpha$-subunit in tissue slides. DAs reduced gonadotropin secretion in vitro [95] and in vivo [96]. Clinically significant tumour shrinkage under BRC therapy has been reported in small studies [97] and case reports [98]. Five small studies [99-103] including 54 NFPA patients have reported the use of vari-

New Mechanisms and Applications of Cabergoline ous doses of CAB (1-3 mg/week) during short periods (6-12 months) for treatment. Despite the small number of patients in all the studies and the lack of untreated control groups in most of the studies, the pooled results indicated tumour stabilization in over $80 \%$ of patients. In a recent review, 79 patients after partial transsphenoidal resection of NFPA (remnant size $>10 \mathrm{~mm}$ in $80 \%$ of patients) were treated with $\mathrm{CAB}$ (mean weekly dose $1.5 \mathrm{mg}$, range $0.5-3.5 \mathrm{mg}$ ) during a mean period of 8.8 years (range 1-24 years), either following detection of tumour remnant in the first post-operative MRI $(n=55)$, or when tumour growth was discovered during conservative follow-up (remedial treatment, $n=24$ ). Preventive treatment resulted in overall tumour control in $87.3 \%$ of patients (38.2\% tumour shrinkage, $49.1 \%$ tumour stabilization), in comparison with $46.7 \%$ in the untreated control group $(n=60)$ [104]. The 15-year progression-free survival rates were $0.805,0.24$, and 0.04 , for the preventive treatment, remedial treatment, and control groups, respectively $(p<0.001)$. Forty-two percent of patients in the control group required additional surgery or radiotherapy, while only 38 and $13 \%$ subjects in the remedial treatment and preventive treatment groups, respectively, required additional therapies $(p=0.002)$ [105]. We reviewed articles from 2000 to 2019 that reported the use of various doses of $\mathrm{CAB}$ and different periods of therapy in 113 NFPA patients. Tumour shrinkage and tumour stabilization was reported in 37.5 and $53.1 \%$ of the patients. And only $9.7 \%$ patients were noted with tumour growth [99-103, 105, 106] (Table 2). The expression of dopamine receptors, especially DRD2, in most NFPAs was considered to be the basis for targeted medical therapies [107]. Surprisingly, tumour response to DA treatment was not related to $\mathrm{DRD} 2$ protein or mRNA expression in tumour tissue as examined by immunohistochemistry and quantitative RT-PCR $[105,106]$, suggesting the involvement of other dopamine receptors. Indeed, we have shown recently that instead of DRD2, DRD5 was the major receptor responsible for dopamine induced activation of mTOR pathway and ACD [5]. Recently, Batista et al. [106] have conducted a randomized clinical trial (NCT03271918) which showed that CAB was an effective drug for treating residual NFPA, and its use was associated with a high rate of tumour shrinkage. Further double-blind, randomized studies should be performed to confirm the effectiveness of CAB treatment for NFPAs.

\section{Cushing's Disease}

$\mathrm{CD}$ is caused by a corticotroph tumour in the pituitary. Patients with $\mathrm{CD}$ are usually treated with transsphenoidal 
Table 2. Studies on cabergoline treatment of non-functioning pituitary adenomas

\begin{tabular}{|c|c|c|c|c|c|c|c|c|}
\hline Lohmann & 2001 & 99 & 13 & 12 & 1 & 7 & 5 & 1 \\
\hline de Herder & 2006 & 101 & 4 & 60 & $1-2$ & 1 & 3 & 0 \\
\hline Garcia & 2013 & 102 & 19 & 6 & 2 & 6 & 9 & 4 \\
\hline Vieira Neto & 2015 & 103 & 9 & 12 & 3 & 7 & 2 & 0 \\
\hline Preventive & & 105 & 55 & $105 \pm 78$ & $1.5 \pm 0.7$ & 21 & 27 & 7 \\
\hline Remedial & & 105 & 24 & & & 7 & 7 & 10 \\
\hline Total & & & 192 & & & $70(36.5 \%)$ & $94(49.0 \%)$ & $28(14.6 \%)$ \\
\hline
\end{tabular}

surgery, as this approach leads to remission in $70-90 \%$ of cases and is associated with low morbidity when performed by experienced surgeons. Nonetheless, among patients in postoperative remission, the risk of recurrence of CD could reach $20-25 \%$ in the 10 years following surgery [108]. Patients with persistent or recurrent CD require additional treatments, including pituitary radiotherapy, adrenal surgery, and/or medical therapy [109]. Medical therapy has recently acquired a more important role, particularly as presurgical treatment for severe disease; as a postsurgical treatment, in cases of failure or incomplete surgical tumour resection; or as bridging therapy before, during, and after radiotherapy while waiting for disease control [109]. Here, we focus on the treatment effect of DAs, especially CAB, on Cushing adenomas (Table 3) $[110,113-119]$. Although DRD2 is expressed in approximately $80 \%$ of corticotroph pituitary adenomas, sustained therapeutic response is not observed in most patients [110]. The role of BRC in the treatment of CD has been previously debated [111]. In a meta-analysis of some earlier small studies and case reports including 23 patients followed for 3-180 weeks, BRC at doses of 1.25$30 \mathrm{mg} /$ day led to normalization of steroid secretion in $48 \%$ of the patients [112]. Pivonello et al. [113] showed that cortisol levels were persistently controlled in 8 (40\%) patients at a median CAB dose of $3.5 \mathrm{mg} /$ week $(1-7 \mathrm{mg} /$ week) without side effects at the 24 -month follow-up. Additionally, $15(75 \%)$ patients were responsive to $\mathrm{CAB}$ treatment after short-term treatment, and half of the patients with a short-term responsiveness continued to respond with stable normal cortisol levels for a period as long as 2 years. Only 5 patients were completely resistant to $\mathrm{CAB}$ treatment. These data suggest that the $\mathrm{CAB}$ dose and the period of treatment necessary to normalize cortisol secretion were extremely variable for each patient with CD [113].

Another retrospective analysis showed that treatment of $\mathrm{CD}$ patients with $\mathrm{CAB}$ resulted in complete response in 11 patients $(36.6 \%)$ and partial response in 4 patients (13.3\%) within 3-6 months. After long-term therapy, 9 patients (30\%) maintained a complete response after a mean of 37 months (range from 12 to 60 months) with a mean dose of $2.1 \mathrm{mg} /$ week of CAB [114]. Recently, a retrospective analysis by Ferriere et al. [115] showed that approximately $20-25 \%$ of CD patients are good responders to $\mathrm{CAB}$ therapy allowing long-term control of hypercortisolism at relatively low dosages and with acceptable tolerability. Therefore, CAB monotherapy could provide an effective long-term medical therapy for selected patients with CD. Another study demonstrated that while $\mathrm{CAB}$ monotherapy was able to reverse hypercortisolism in $25 \%$ of patients, the addition of relatively low doses of ketoconazole led to normalization of urinary free cortisol in approximately two-thirds of patients who did not achieve a full response to $\mathrm{CAB}$ alone [116]. Although the combined treatment lowered patients' late-night salivary cortisol levels, they remained higher than normal, indicating a persistent subclinical hypercortisolism; meanwhile, no differences emerged between the two treatment schedules (CAB with added ketoconazole, or ketoconazole with added CAB) [117]. No serious adverse events were reported during the treatment. Lila et al. [118] treated 20 patients with persistent or recurrent CD for up to 1 year with $C A B$ after surgery. With an initial dose of $1 \mathrm{mg} /$ week, and a subsequent increase up to $5 \mathrm{mg} /$ week depending on responses, $28 \%$ of patients achieved normal- 
Table 3. Studies on cabergoline treatment of Cushing's disease

\begin{tabular}{|c|c|c|c|c|c|c|}
\hline First author & Year & Ref. & Patients, $n$ & Follow-up & Dose/week & Controlled hypercortisolism, \% \\
\hline Pivonello & 2004 & 110 & 10 & 3 & $1-3$ & 40 \\
\hline Pivonello & 2009 & 113 & 20 & 24 & $1-7$ & $\begin{array}{l}35 \text { (short term) } \\
40 \text { (long term) }\end{array}$ \\
\hline Vilar & 2010 & 116 & 12 & 6 & $2-3$ & 25 \\
\hline Lila & 2010 & 118 & 20 & 12 & $1.0-5.0$ & 28 \\
\hline Barbot & 2014 & 117 & 14 & 12 & $0.5-3.0$ & $\begin{array}{l}33 \text { (short term, monotherapy) } \\
100 \text { (long term, bitherapy) }\end{array}$ \\
\hline Burman & 2016 & 119 & 20 & 1.5 & $2.5-5.0$ & 0 \\
\hline Ferriere & 2017 & 115 & 53 & 12 & $0.5-6$ & 40 \\
\hline
\end{tabular}

ization of midnight serum cortisol and/or normalization during dexamethasone suppression testing. Lower baseline serum cortisol values were predictive of a therapeutic response. However, Burman et al. [119] demonstrated that CAB seems to be of little value in the management of $\mathrm{CD}$ in short-term treatment.

In summary, small prospective studies have evaluated the impact of $\mathrm{CAB}$ treatment in patients with Cushing syndrome. Normalization of urinary free cortisol or serum cortisol response levels of $25-35 \%$ was achieved within 3-6 months $[113,116]$. Longer-term response rates of $22-50 \%$ up to 24 months of treatment have also been reported in some studies $[113,116,118]$. However, during long-term follow-up, patients with initial normalization of urinary free cortisol experienced relapse after 2 years, resulting in a long-term response rate of approximately $30 \%[113,116,118]$. In the future, larger, multicentre studies will determine the efficacy and safety of $\mathrm{CAB}$ in the treatment of $\mathrm{CD}$.

\section{Other Potential Applications}

\section{$C A B$ in Combination with Other Drugs in Pituitary} Adenomas

Recent studies have explored the combination of DAs with other drugs to increase the efficacy. For example, it has been reported that in 2 patients who had prolactinomas resistant to high-dose $\mathrm{CAB}$, addition of lapatinib, a tyrosine-kinase inhibitor targeting EGFR and erbB2 tyrosine-kinase approved in breast cancer treatment, to $\mathrm{CAB}$ treatment achieved positive responses [120]. The addition of an SSA octreotide to ongoing CAB treatment may be effective in some patients with DA-resistant macroprolactinomas, independent of the adenoma's SSTR expression profile [121]. Meanwhile, the addition of pasireotide may be effective in some DA-resistant macroprolactinomas, which had high SSTR5 and lowSSTR2 expression in pathological analysis [122]. Metformin is the first-line medication for the treatment of type 2 diabetes, particularly in people who are overweight. A pilot study demonstrated that 2 patients with BRC-resistant prolactinomas administrated with BRC combined with metformin subsequently exhibited normal PRL levels and remarkable tumour shrinkage [123].

In an in vitro study using rat pituitary $\mathrm{GH} 3$ and $\mathrm{MMQ}$ cell lines, BRC was combined with artesunate (ART), a natural sesquiterpene lactone derivative of artemisinin that is primarily used as an antimalarial drug. In these cells, BRC and ART combination synergistically inhibited cell proliferation, induced apoptosis, attenuated cell migration and invasion, and suppressed PRL secretion; although ART alone had none of these effects [124].

Chloroquine (CQ), another medication used to prevent and to treat malaria, has been used as an autophagy inhibitor [125]. We recently reported that in GH3 and MMQ cell lines, as well as in vivo xenograft mouse models and oestrogen-induced rat prolactinoma models, combinations of CAB and CQ achieved a higher level of growth inhibition and tumour suppression than individual treatments, suggesting that the combined use of $\mathrm{CAB}$ and CQ may increase clinical effectiveness in the treatment of human pituitary adenomas [126]. A clinical trial using $\mathrm{CQ}$ and $\mathrm{CAB}$ in resistant prolactinomas is currently ongoing (NCT03400865). 
Potential Use of CAB for Other Cancers

Since dopamine receptors are expressed in many tissue types, the use of DAs in the treatment of other cancer types has been suggested. High DRD2 expression has been reported in pancreatic neuroendocrine tumours, suggesting the potential use of $\mathrm{CAB}$ in this type of tumours [127]. Elevated DRD2 expression was also found in human lung cancer tissues and correlated with tumour progression; in the human lung carcinoid cell line NCI-H727, the tumour-suppressive effects of mTOR inhibitors were potentiated by $\mathrm{CAB}$ with octreotide, an SSA; however, CAB or octreotide alone had no anti-proliferative effect in vitro [128]. In addition to DRD2, in vitro studies have shown DRD1 expression in breast cancers; and fenoldopam, a high-affinity DRD1 agonist, significantly suppressed cell viability and invasion, and induced apoptosis in the breast cancer cell lines MDA-MB-231 and MDA-MB-468, through the cGMP/PKG signalling pathway [129]. According to The Cancer Genome Atlas (TCGA), high DRD5 expression was found in the majority of human cancers; and we have recently confirmed DRD5 expression in multiple human cancer cell lines, including colon cancer, gastric cancer, and glioblastomas. DRD5-specific agonists significantly suppressed cell viability in these cells in vitro through suppression of mTOR signalling and induction of ACD [5].

In nude mice implanted with the breast cancer cell line MCF-7 and the colon cancer cell line HT29, CAB enhanced the anti-tumour effects of the chemotherapeutic drugs doxorubicin and 5-fluorouracil [130]. In addition, $\mathrm{CAB}$ has been found to suppress cancer progression by reducing angiogenesis and tumour-infiltrating myeloidderived suppressor cells in vivo [38].

In patients with metastatic breast cancer, a higher tumour regression rate was observed in patients treated with the chemotherapeutic drug Taxotere (TXT) plus CAB than in patients treated with TXT alone (31/34 vs. 13/36). In addition, chemotherapy-induced asthenia was significantly lower in patients treated with TXT/ $\mathrm{CAB}$ combination compared to the patients treated with TXT alone (5/34 vs. 11/36). No CAB-related toxicity was observed in this study [131]. A recent pilot study showed that when patients with metastatic breast cancer were given CAB ( $1 \mathrm{mg}$ orally, twice weekly), the clinical benefit rate at 2 months was observed in $33 \%$ of the patients (6/18) [132]. Taken together, these data strongly suggest the potential of $\mathrm{CAB}$ for the treatment of different cancer types with or without chemotherapeutic drugs.

\section{Conclusions}

$\mathrm{CAB}$ has been used as the first-line treatment for prolactinomas for a long time. Its mechanism of suppressing PRL production and secretion by activating DRD2 and inhibiting cAMP has been well documented. Recent studies have revealed different mechanisms for its growth-suppressive functions. We have recently demonstrated a novel mechanism by which CAB initiates autophagy but blocks autophagic flux, thus inducing cell death, via DRD5. Synergistic anti-tumour effects were reported when $\mathrm{CAB}$ was combined with other drugs for cancer treatment. These studies suggest a potential broad use of $\mathrm{CAB}$ in the treatment of different cancer types. Future studies of the molecular mechanisms of $\mathrm{CAB}$ functions and type-specific dopamine receptor expression in different cancers will not only provide novel insights for targeted clinical use of DAs but may also generate new information for their molecular targets, which will be important for modifying drugs to overcome adverse effects and drug resistance. Double-blind, randomized clinical trials with a large patient population and multiple centres will demonstrate the efficacy and safety of the broader clinical use of $\mathrm{CAB}$ and other DAs.

\section{Disclosure Statement}

The authors have declared that no conflict of interest exists.

\section{Funding Sources}

This work was supported by the National Natural Science Foundation of China (grant Nos. 81471392, 81671371 to Z.B.W, and 81701359 to S.L.), and Shanghai Municipal Education Commission-Gaofeng Clinical Medicine Grant Support (grant No. 20161407 to Z.B.W), and Shanghai Science and Technology Commission (grant No. 18XD1403400 to Z.B.W).

\section{References}

1 Colao A, Savastano S. Medical treatment of prolactinomas. Nat Rev Endocrinol. 2011 May;7(5):267-78.

2 Pascal-Vigneron V, Weryha G, Bosc M, Leclere J. [Hyperprolactinemic amenorrhea: treatment with cabergoline versus bromocriptine. Results of a national multicenter randomized double-blind study]. Presse Med. 1995 Apr;24(16):753-7.

3 Di Sarno A, Landi ML, Cappabianca P, Di Salle F, Rossi FW, Pivonello R, et al. Resistance to cabergoline as compared with bromocriptine in hyperprolactinemia: prevalence, clinical definition, and therapeutic strategy. J Clin Endocrinol Metab. 2001 Nov;86(11):5256-61. 
4 Huang HY, Zhai W, Tang H, Hui GZ, Wu ZB. Cabergoline for the treatment of bromocriptine-resistant invasive giant prolactinomas. Endocrine. 2018 Nov;62(2):464-9.

5 Leng ZG, Lin SJ, Wu ZR, Guo YH, Cai L, Shang HB, et al. Activation of DRD5 (dopamine receptor D5) inhibits tumor growth by autophagic cell death. Autophagy. 2017 Aug; 13(8):1404-19.

6 Kuhn E, Chanson P. Cabergoline in acromegaly. Pituitary. 2017 Feb;20(1):121-8.

7 Lee SY, Kim JH, Lee JH, Kim YH, Cha HJ, Kim SW, et al. The efficacy of medical treatment in patients with acromegaly in clinical practice. Endocr J. 2018 Jan;65(1):33-41.

8 Greenman Y, Cooper O, Yaish I, Robenshtok E, Sagiv N, Jonas-Kimchi T, et al: Treatment of clinically nonfunctioning pituitary adenomas with dopamine agonists. Eur J Endocrinol. 2016 Jul;175(1):63-72.

9 Petrossians P, Thonnard AS, Beckers A. Medical treatment in Cushing's syndrome: dopamine agonists and cabergoline. Neuroendocrinology. 2010;92 Suppl 1:116-9.

10 Colao A, Lombardi G, Annunziato L. Cabergoline. Expert Opin Pharmacother. 2000 Mar; 1(3):555-74.

11 Cooper O, Greenman Y. Dopamine Agonists for Pituitary Adenomas. Front Endocrinol (Lausanne). 2018 Aug;9:469.

12 Ben-Jonathan N, Hnasko R. Dopamine as a prolactin (PRL) inhibitor. Endocr Rev. 2001 Dec;22(6):724-63.

13 Fitzgerald P, Dinan TG. Prolactin and dopamine: what is the connection? A review article. J Psychopharmacol. 2008 Mar;22(2 Suppl):12-9.

14 Freeman ME, Kanyicska B, Lerant A, Nagy G Prolactin: structure, function, and regulation of secretion. Physiol Rev. 2000 Oct;80(4): 1523-631.

15 Usiello A, Baik JH, Rougé-Pont F, Picetti R, Dierich A, LeMeur M, et al. Distinct functions of the two isoforms of dopamine D2 receptors. Nature. 2000 Nov;408(6809):199-203.

16 Hervé DS, Girault J-A: Chapter II Signal transduction of dopamine receptors. In: Dunnett SB, Bentivoglio M. Björklund A, Hökfelt T, editors: Handbook of Chemical Neuroanatomy. Amsterdam: Elsevier; 2005. vol 21. pp 109-151.

17 Spada A, Nicosia S, Cortelazzi L, Pezzo G, Bassetti M, Sartorio A, et al. In vitro studies on prolactin release and adenylate cyclase activity in human prolactin-secreting pituitary adenomas. Different sensitivity of macro- and microadenomas to dopamine and vasoactive intestinal polypeptide. J Clin Endocrinol Metab. 1983 Jan;56(1):1-10.

18 Maurer RA. Transcriptional regulation of the prolactin gene by ergocryptine and cyclic AMP. Nature. 1981 Nov;294(5836):94-7.
19 Andreotti AC, Pianezzola E, Persiani S, Pacciarini MA, Strolin Benedetti M, Pontiroli AE. Pharmacokinetics, pharmacodynamics, and tolerability of cabergoline, a prolactin-lowering drug, after administration of increasing oral doses $(0.5,1.0$, and 1.5 milligrams) in healthy male volunteers. J Clin Endocrinol Metab. 1995 Mar;80(3):841-5.

20 Kelly MA, Rubinstein M, Asa SL, Zhang G, Saez C, Bunzow JR, et al. Pituitary lactotroph hyperplasia and chronic hyperprolactinemia in dopamine D2 receptor-deficient mice. Neuron. 1997 Jul;19(1):103-13.

21 Saiardi A, Bozzi Y, Baik JH, Borrelli E. Antiproliferative role of dopamine: loss of D2 receptors causes hormonal dysfunction and pituitary hyperplasia. Neuron. 1997 Jul;19(1): $115-26$.

22 Radl DB, Zárate S, Jaita G, Ferraris J, Zaldivar V, Eijo G, et al. Apoptosis of lactotrophs induced by $\mathrm{D} 2$ receptor activation is estrogen dependent. Neuroendocrinology. 2008;88(1): 43-52.

23 Vasilev V, Daly AF, Vroonen L, Zacharieva S, Beckers A. Resistant prolactinomas. J Endocrinol Invest. 2011 Apr;34(4):312-6.

24 Lin SJ, Leng ZG, Guo YH, Cai L, Cai Y, Li N, et al. Suppression of mTOR pathway and induction of autophagy-dependent cell death by cabergoline. Oncotarget. 2015 Nov;6(36): 39329-41.

25 Iaccarino C, Samad TA, Mathis C, Kercret H, Picetti R, Borrelli E. Control of lactotrop proliferation by dopamine: essential role of signaling through D2 receptors and ERKs. Proc Natl Acad Sci USA. 2002 Oct;99(22):14530-5.

26 Welsh GI, Hall DA, Warnes A, Strange PG, Proud CG. Activation of microtubule-associated protein kinase (Erk) and p70 S6 kinase by D2 dopamine receptors. J Neurochem. 1998 May;70(5):2139-46.

27 An JJ, Cho SR, Jeong DW, Park KW, Ahn YS, Baik JH. Anti-proliferative effects and cell death mediated by two isoforms of dopamine D2 receptors in pituitary tumor cells. Mol Cell Endocrinol. 2003 Aug;206(1-2):49-62.

28 Peverelli E, Olgiati L, Locatelli M, Magni P, Fustini MF, Frank G, et al. The dopamine-somatostatin chimeric compound BIM-23A760 exerts antiproliferative and cytotoxic effects in human non-functioning pituitary tumors by activating ERK1/2 and p38 pathways. Cancer Lett. 2010 Feb;288(2):170-6.

29 Laplante M, Sabatini DM. mTOR signaling in growth control and disease. Cell. 2012 Apr; 149(2):274-93.

30 Neufeld TP. TOR-dependent control of autophagy: biting the hand that feeds. Curr Opin Cell Biol. 2010 Apr;22(2):157-68.

31 Vivanco I, Sawyers CL. The phosphatidylinositol 3-Kinase AKT pathway in human cancer. Nat Rev Cancer. 2002 Jul;2(7):489-501.

32 Martini M, De Santis MC, Braccini L, Gulluni F, Hirsch E. PI3K/AKT signaling pathway and cancer: an updated review. Ann Med. 2014 Sep;46(6):372-83.
33 Beaulieu JM, Tirotta E, Sotnikova TD, Masri B, Salahpour A, Gainetdinov RR, et al. Regulation of Akt signaling by D2 and D3 dopamine receptors in vivo. J Neurosci. 2007 Jan; 27(4):881-5.

34 Geng X, Ma L, Li Z, Li Z, Li J, Li M, et al. Bromocriptine Induces Autophagy-Dependent Cell Death in Pituitary Adenomas. World Neurosurg. 2017 Apr;100:407-16.

35 Basu S, Nagy JA, Pal S, Vasile E, Eckelhoefer IA, Bliss VS, et al. The neurotransmitter dopamine inhibits angiogenesis induced by vascular permeability factor/vascular endothelial growth factor. Nat Med. 2001 May;7(5):56974.

36 Basu S, Sarkar C, Chakroborty D, Nagy J, Mitra RB, Dasgupta PS, et al. Ablation of peripheral dopaminergic nerves stimulates malignant tumor growth by inducing vascular permeability factor/vascular endothelial growth factor-mediated angiogenesis. Cancer Res. 2004 Aug;64(16):5551-5.

37 Novella-Maestre E, Carda C, Noguera I, RuizSaurí A, García-Velasco JA, Simón C, et al. Dopamine agonist administration causes a reduction in endometrial implants through modulation of angiogenesis in experimentally induced endometriosis. Hum Reprod. 2009 May;24(5):1025-35.

38 Hoeppner LH, Wang Y, Sharma A, Javeed N, Van Keulen VP, Wang E, et al. Dopamine D2 receptor agonists inhibit lung cancer progression by reducing angiogenesis and tumor infiltrating myeloid derived suppressor cells. Mol Oncol. 2015 Jan;9(1):270-81.

39 Fritz R, Kohan-Ghadr HR, Bolnick JM, Bolnick AD, Kilburn BA, Diamond MP, et al. Noninvasive detection of trophoblast protein signatures linked to early pregnancy loss using trophoblast retrieval and isolation from the cervix (TRIC). Fertil Steril. 2015;104:339346 e334.

40 Ishikawa H, Heaney AP, Yu R, Horwitz GA, Melmed S. Human pituitary tumor-transforming gene induces angiogenesis. J Clin Endocrinol Metab. 2001 Feb;86(2):867-74.

41 Banerjee SK, Sarkar DK, Weston AP, De A, Campbell DR. Over expression of vascular endothelial growth factor and its receptor during the development of estrogen-induced rat pituitary tumors may mediate estrogeninitiated tumor angiogenesis. Carcinogenesis. 1997 Jun;18(6):1155-61.

42 Minematsu T, Suzuki M, Sanno N, Takekoshi S, Teramoto A, Osamura RY. PTTG overexpression is correlated with angiogenesis in human pituitary adenomas. Endocr Pathol. 2006;17(2):143-53.

43 Cristina C, Perez-Millan MI, Luque G, Dulce RA, Sevlever G, Berner SI, et al. VEGF and CD31 association in pituitary adenomas. Endocr Pathol. 2010 Sep;21(3):154-60.
New Mechanisms and Applications of Cabergoline
Neuroendocrinology 2020;110:477-488 DOI: $10.1159 / 000504000$ 
44 Mallea-Gil MS, Cristina C, Perez-Millan MI, Villafañe AM, Ballarino C, Stalldecker G, et al. Invasive giant prolactinoma with loss of therapeutic response to cabergoline: expression of angiogenic markers. Endocr Pathol. 2009; 20(1):35-40.

45 Molitch ME. Diagnosis and Treatment of Pituitary Adenomas: A Review. JAMA. 2017 Feb;317(5):516-24.

46 Melmed S, Casanueva FF, Hoffman AR, Kleinberg DL, Montori VM, Schlechte JA, et al.; Endocrine Society. Diagnosis and treatment of hyperprolactinemia: an Endocrine Society clinical practice guideline. J Clin Endocrinol Metab. 2011 Feb;96(2):273-88.

47 Huang HY, Lin SJ, Zhao WG, Wu ZB: Cabergoline versus bromocriptine for the treatment of giant prolactinomas: A quantitative and systematic review. Metab Brain Dis. 2018;33: 969-976.

48 Verhelst J, Abs R, Maiter D, van den Bruel A, Vandeweghe M, Velkeniers B, et al. Cabergoline in the treatment of hyperprolactinemia: a study in 455 patients. J Clin Endocrinol Metab. 1999 Jul;84(7):2518-22.

49 Colao A, Di Sarno A, Landi ML, Scavuzzo F, Cappabianca P, Pivonello R, et al. Macroprolactinoma shrinkage during cabergoline treatment is greater in naive patients than in patients pretreated with other dopamine agonists: a prospective study in 110 patients. J Clin Endocrinol Metab. 2000 Jun;85(6):224752.

50 Corsello SM, Ubertini G, Altomare M, Lovicu RM, Migneco MG, Rota CA, et al. Giant prolactinomas in men: efficacy of cabergoline treatment. Clin Endocrinol (Oxf). 2003 May; 58(5):662-70

51 Colao A, Sarno AD, Cappabianca P, Briganti F, Pivonello R, Somma CD, et al. Gender differences in the prevalence, clinical features and response to cabergoline in hyperprolactinemia. Eur J Endocrinol. 2003;148:325-331.

52 Colao A, Di Sarno A, Cappabianca P, Di Somma C, Pivonello R, Lombardi G. Withdrawal of long-term cabergoline therapy for tumoral and nontumoral hyperprolactinemia. N Engl J Med. 2003 Nov;349(21):2023-33.

53 Colao A, Vitale G, Cappabianca P, Briganti F, Ciccarelli A, De Rosa M, et al. Outcome of cabergoline treatment in men with prolactinoma: effects of a 24-month treatment on prolactin levels, tumor mass, recovery of pituitary function, and semen analysis. J Clin Endocrinol Metab. 2004 Apr;89(4):1704-11.

54 De Rosa M, Ciccarelli A, Zarrilli S, Guerra E, Gaccione M, Di Sarno A, et al. The treatment with cabergoline for 24 month normalizes the quality of seminal fluid in hyperprolactinaemic males. Clin Endocrinol (Oxf). 2006 Mar; 64(3):307-13.

55 Shimon I, Benbassat C, Hadani M. Effectiveness of long-term cabergoline treatment for giant prolactinoma: study of 12 men. Eur J Endocrinol. $2007 \mathrm{Feb}$;156(2):225-31.
56 Ono M, Miki N, Kawamata T, Makino R, Amano K, Seki T, et al. Prospective study of high-dose cabergoline treatment of prolactinomas in 150 patients. J Clin Endocrinol Metab. 2008;93(12):4721-7.

57 Vallette S, Serri K, Rivera J, Santagata P, Delorme S, Garfield N, et al. Long-term cabergoline therapy is not associated with valvular heart disease in patients with prolactinomas. Pituitary. 2009;12(3):153-7.

58 Cho EH, Lee SA, Chung JY, Koh EH, Cho YH, Kim JH, et al. Efficacy and safety of cabergoline as first line treatment for invasive giant prolactinoma. J Korean Med Sci. 2009 Oct; 24(5):874-8.

59 Delgrange E, Daems T, Verhelst J, Abs R, Maiter D: Characterization of resistance to the prolactin-lowering effects of cabergoline in macroprolactinomas: a study in $122 \mathrm{pa}$ tients. Eur J Endocrinol. 2009;160:747-752.

60 Lombardi M, Lupi I, Cosottini M, Rossi G, Manetti L, Raffaelli V, et al. Lower prolactin levels during cabergoline treatment are associated to tumor shrinkage in prolactin secreting pituitary adenoma. Horm Metab Res. 2014 Dec;46(13):939-42.

61 Pala NA, Laway BA, Misgar RA, Dar RA. Metabolic abnormalities in patients with prolactinoma: response to treatment with cabergoline. Diabetol Metab Syndr. 2015 Nov; 7(1):99.

62 Shrivastava RK, Arginteanu MS, King WA, Post KD. Giant prolactinomas: clinical management and long-term follow up. J Neurosurg. 2002 Aug;97(2):299-306.

63 Hamidi O, Van Gompel J, Gruber L, Kittah NE, Donegan D, et al. Management and Outcomes of Giant Prolactinoma: A Series of 71 Patients. Endocr Pract. 2019;25:340-352.

64 Shimon I. Giant Prolactinomas. Neuroendocrinology. 2019;109(1):51-6.

65 Espinosa E, Sosa E, Mendoza V, Ramírez C, Melgar V, Mercado M. Giant prolactinomas: are they really different from ordinary macroprolactinomas? Endocrine. 2016 Jun;52(3): 652-9.

66 Shimon I, Sosa E, Mendoza V, Greenman Y, Tirosh A, Espinosa E, et al. Giant prolactinomas larger than $60 \mathrm{~mm}$ in size: a cohort of massive and aggressive prolactin-secreting pituitary adenomas. Pituitary. 2016 Aug; 19(4):429-36.

67 Acharya SV, Gopal RA, Menon PS, Bandgar TR, Shah NS: Giant prolactinoma and effectiveness of medical management. Endocr Pract. 2010;16:42-46.

68 Lim S, Shahinian H, Maya MM, Yong W, Heaney AP. Temozolomide: a novel treatment for pituitary carcinoma. Lancet Oncol. 2006 Jun;7(6):518-20.

69 Baldari S, Ferraù F, Alafaci C, Herberg A, Granata F, Militano V, et al. First demonstration of the effectiveness of peptide receptor radionuclide therapy (PRRT) with 111In-DTPA-octreotide in a giant PRL-secreting pituitary adenoma resistant to conventional treatment. Pituitary. 2012 Dec;15(S1 Suppl 1): S57-60.
70 Oh MC, Aghi MK. Dopamine agonist-resistant prolactinomas. J Neurosurg. 2011 May; 114(5):1369-79.

71 Maiter D. Management of Dopamine Agonist-Resistant Prolactinoma. Neuroendocrinology. 2019;109(1):42-50.

72 Delgrange E, Maiter D, Donckier J: Effects of the dopamine agonist cabergoline in patients with prolactinoma intolerant or resistant to bromocriptine. Eur J Endocrinol. 1996;134: 454-456.

$73 \mathrm{Wu}$ ZB, Zheng WM, Su ZP, Chen Y, Wu JS, Wang $C D$, et al. Expression of D2RmRNA isoforms and ERmRNA isoforms in prolactinomas: correlation with the response to bromocriptine and with tumor biological behavior. J Neurooncol. 2010 Aug;99(1):25-32.

74 Radl DB, Ferraris J, Boti V, Seilicovich A, Sarkar DK, Pisera D. Dopamine-induced apoptosis of lactotropes is mediated by the short isoform of D2 receptor. PLoS One. 2011 Mar;6(3):e18097.

75 Caccavelli L, Feron F, Morange I, Rouer E, Benarous R, Dewailly D, et al. Decreased expression of the two D2 dopamine receptor isoforms in bromocriptine-resistant prolactinomas. Neuroendocrinology. 1994 Sep;60(3): 314-22.

76 Heiman ML, Ben-Jonathan N. Rat anterior pituitary dopaminergic receptors are regulated by estradiol and during lactation. Endocrinology. 1982 Oct;111(4):1057-60.

77 Wang F, Gao H, Li C, Bai J, Lu R, Cao L, et al. Low levels of PRB3 mRNA are associated with dopamine-agonist resistance and tumor recurrence in prolactinomas. J Neurooncol. 2014 Jan;116(1):83-8.

78 Li Z, Liu Q, Li C, Zong X, Bai J, Wu Y, et al. The role of TGF- $\beta /$ Smad signaling in dopamine agonist-resistant prolactinomas. $\mathrm{Mol}$ Cell Endocrinol. 2015 Feb;402:64-71.

$79 \mathrm{Hu}$ B, Mao Z, Jiang X, He D, Wang Z, Wang $X$, et al. Role of TGF- $\beta 1 / \mathrm{Smad} 3$-mediated fibrosis in drug resistance mechanism of prolactinoma. Brain Res. 2018 Nov; 1698:204-12.

80 Gillam MP, Middler S, Freed DJ, Molitch ME. The novel use of very high doses of cabergoline and a combination of testosterone and an aromatase inhibitor in the treatment of a giant prolactinoma. J Clin Endocrinol Metab. 2002 Oct;87(10):4447-51.

81 Kast RE, Altschuler EL. Dopamine agonists and valvular heart disease. N Engl J Med. 2007 Apr;356(16):1677.

82 Simonis G, Fuhrmann JT, Strasser RH. Metaanalysis of heart valve abnormalities in Parkinson's disease patients treated with dopamine agonists. Mov Disord. 2007 Oct;22(13): 1936-42.

83 Stiles CE, Tetteh-Wayoe ET, Bestwick J, Steeds RP, Drake WM. A meta-analysis of the prevalence of cardiac valvulopathy in hyperprolactinemic patients treated with Cabergoline. J Clin Endocrinol Metab. 2018 Sep. 
84 Drake WM, Stiles CE, Bevan JS, Karavitaki N, Trainer PJ, Rees DA, et al.; UK Cabergoline valvulopathy study group. A Follow-Up Study of the Prevalence of Valvular Heart Abnormalities in Hyperprolactinemic Patients Treated With Cabergoline. J Clin Endocrinol Metab. 2016 Nov;101(11):4189-94.

85 Melmed S. Medical progress: acromegaly. N Engl J Med. 2006 Dec;355(24):2558-73.

86 Katznelson L, Laws ER Jr, Melmed S, Molitch ME, Murad MH, Utz A, et al.; Endocrine Society. Acromegaly: an endocrine society clinical practice guideline. J Clin Endocrinol Metab. 2014 Nov;99(11):3933-51.

87 Abs R, Verhelst J, Maiter D, Van Acker K, Nobels F, Coolens JL, et al. Cabergoline in the treatment of acromegaly: a study in $64 \mathrm{pa}-$ tients. J Clin Endocrinol Metab. 1998 Feb; 83(2):374-8.

88 Jackson SN, Fowler J, Howlett TA. Cabergoline treatment of acromegaly: a preliminary dose finding study. Clin Endocrinol (Oxf). 1997 Jun;46(6):745-9.

89 Bression D, Brandi AM, Nousbaum A, Le Dafniet M, Racadot J, Peillon F. Evidence of dopamine receptors in human growth hormone $(\mathrm{GH})$-secreting adenomas with concomitant study of dopamine inhibition of $\mathrm{GH}$ secretion in a perifusion system. J Clin Endocrinol Metab. 1982 Sep;55(3):589-93.

90 Ben-Shlomo A, Liu NA, Melmed S. Somatostatin and dopamine receptor regulation of pituitary somatotroph adenomas. Pituitary. $2017 \mathrm{Feb}$;20(1):93-9.

91 Missale C, Nash SR, Robinson SW, Jaber M, Caron MG. Dopamine receptors: from structure to function. Physiol Rev. 1998 Jan;78(1): 189-225.

92 Marazuela M, Ramos-Leví A, SampedroNúñez M, Bernabeu I. Cabergoline treatment in acromegaly: pros. Endocrine. 2014 Jun; 46(2):215-9.

93 Higham CE, Atkinson AB, Aylwin S, Bidlingmaier M, Drake WM, Lewis A, et al. Effective combination treatment with cabergoline and low-dose pegvisomant in active acromegaly: a prospective clinical trial. J Clin Endocrinol Metab. 2012 Apr;97(4):1187-93.

94 Al-Shraim M, Asa SL. The 2004 World Health Organization classification of pituitary tumors: what is new? Acta Neuropathol. 2006 Jan;111(1):1-7.

95 Kwekkeboom DJ, Hofland LJ, van Koetsveld PM, Singh R, van den Berge JH, Lamberts SW. Bromocriptine increasingly suppresses the in vitro gonadotropin and alpha-subunit release from pituitary adenomas during long term culture. J Clin Endocrinol Metab. 1990 Sep; 71(3):718-24.

96 Kwekkeboom DJ, Lamberts SW. Long-term treatment with the dopamine agonist CV 205502 of patients with a clinically non-functioning, gonadotroph, or alpha-subunit secreting pituitary adenoma. Clin Endocrinol (Oxf). 1992 Feb;36(2):171-6.
97 van Schaardenburg D, Roelfsema F, van Seters AP, Vielvoye GJ. Bromocriptine therapy for non-functioning pituitary adenoma. Clin Endocrinol (Oxf). 1989 May;30(5): 475-84.

98 Colao A, Di Somma C, Pivonello R, Faggiano A, Lombardi G, Savastano S. Medical therapy for clinically non-functioning pituitary adenomas. Endocr Relat Cancer. 2008 Dec;15(4):905-15.

99 Lohmann T, Trantakis C, Biesold M, Prothmann S, Guenzel S, Schober R, et al. Minor tumour shrinkage in nonfunctioning pituitary adenomas by long-term treatment with the dopamine agonist cabergoline. Pituitary. 2001 Aug;4(3):173-8

100 Pivonello R, Matrone C, Filippella M, Cavallo LM, Di Somma C, Cappabianca P, et al. Dopamine receptor expression and function in clinically nonfunctioning pituitary tumors: comparison with the effectiveness of cabergoline treatment. J Clin Endocrinol Metab. 2004 Apr;89(4):1674-83.

101 de Herder WW, Reijs AE, Feelders RA, van Aken MO, Krenning EP, Tanghe HL, et al. Dopamine agonist therapy of clinically nonfunctioning pituitary macroadenomas. Is there a role for 123I-epidepride dopamine D2 receptor imaging? Eur J Endocrinol. 2006 Nov; 155(5):717-23.

102 Garcia EC, Naves LA, Silva AO, de Castro LF, Casulari LA, Azevedo MF. Short-term treatment with cabergoline can lead to tumor shrinkage in patients with nonfunctioning pituitary adenomas. Pituitary. 2013 Jun;16(2):189-94.

103 Vieira Neto L, Wildemberg LE, Moraes AB, Colli LM, Kasuki L, Marques NV, et al. Dopamine receptor subtype 2 expression profile in nonfunctioning pituitary adenomas and in vivo response to cabergoline therapy. Clin Endocrinol (Oxf). 2015 May;82(5): 739-46.

104 Greenman Y: Management of endoctinre disease: present and future perspectives for medical therapy of nonfunctioning pituitary adenomas. Eur JEndocrinol.2017;177:R113R124.

105 Greenman Y, Cooper O, Yaish I, Robenshtok E, Sagiv N, Jonas-Kimchi T, et al. Treatment of clinically nonfunctioning pituitary adenomas with dopamine agonists. Eur J Endocrinol. 2016 Jul;175(1):63-72.

106 Batista RL, Musolino NR, Cescato VA, da Silva GO, Medeiros RS, Herkenhoff CG, et al. Cabergoline in the Management of Residual Nonfunctioning Pituitary Adenoma: A Single-Center, Open-Label, 2-Year Randomized Clinical Trial. Am J Clin Oncol. 2019 Feb;42(2):221-7.

107 Stefaneanu L, Kovacs K, Horvath E, Buchfelder M, Fahlbusch R, Lancranjan L. Dopamine $\mathrm{D} 2$ receptor gene expression in human adenohypophysial adenomas. Endocrine. 2001 Apr;14(3):329-36.
108 Tritos NA, Biller BM, Swearingen B. Management of Cushing disease. Nat Rev Endocrinol. 2011 May;7(5):279-89.

109 Pivonello R, De Leo M, Cozzolino A, Colao A. The Treatment of Cushing's Disease. Endocr Rev. 2015 Aug;36(4):385-486.

110 Pivonello R, Ferone D, de Herder WW, Kros JM, De Caro ML, Arvigo M, et al. Dopamine receptor expression and function in corticotroph pituitary tumors. J Clin Endocrinol Metab. 2004 May;89(5):2452-62.

111 Krieger DT. Physiopathology of Cushing's disease. Endocr Rev. 1983;4(1):22-43.

112 Miller JW, Crapo L. The medical treatment of Cushing's syndrome. Endocr Rev. 1993 Aug;14(4):443-58.

113 Pivonello R, De Martino MC, Cappabianca P, De Leo M, Faggiano A, Lombardi G, et al. The medical treatment of Cushing's disease: effectiveness of chronic treatment with the dopamine agonist cabergoline in patients unsuccessfully treated by surgery. J Clin Endocrinol Metab. 2009 Jan;94(1):223-30.

114 Godbout A, Manavela M, Danilowicz K, Beauregard H, Bruno OD, Lacroix A: Cabergoline monotherapy in the long-term treatment of Cushing's disease. Eur J Endocrinol. 2010;163:709-716.

115 Ferriere A, Cortet C, Chanson P, Delemer B, Caron $\mathrm{P}$, Chabre O, et al: Cabergoline for Cushing's disease: a large retrospective multicenter study. Eur J Endocrinol. 2017;176: 305-314.

116 Vilar L, Naves LA, Azevedo MF, Arruda MJ, Arahata CM, Moura E Silva L, et al. Effectiveness of cabergoline in monotherapy and combined with ketoconazole in the management of Cushing's disease. Pituitary. 2010 Jun;13(2):123-9.

117 Barbot M, Albiger N, Ceccato F, Zilio M, Frigo AC, Denaro L, et al. Combination therapy for Cushing's disease: effectiveness of two schedules of treatment: should we start with cabergoline or ketoconazole? Pituitary. 2014 Apr;17(2):109-17.

118 Lila AR, Gopal RA, Acharya SV, George J, Sarathi V, Bandgar T, et al. Efficacy of cabergoline in uncured (persistent or recurrent) Cushing disease after pituitary surgical treatment with or without radiotherapy. Endocr Pract. 2010 Nov-Dec;16(6):968-76.

119 Burman P, Eden-Engstrom B, Ekman B, Karlsson FA, Schwarcz E, Wahlberg J: Limited value of cabergoline in Cushing's disease: a prospective study of a 6-week treatment in 20 patients. Eur J Endocrinol. 2016; 174:17-24.

120 Cooper O, Mamelak A, Bannykh S, Carmichael J, Bonert V, Lim S, et al. Prolactinoma ErbB receptor expression and targeted therapy for aggressive tumors. Endocrine. 2014 Jun;46(2):318-27. 
121 Sosa-Eroza E, Espinosa E, Ramírez-Rentería C, Mendoza V, Arreola R, Mercado M. Treatment of multiresistant prolactinomas with a combination of cabergoline and octreotide LAR. Endocrine. 2018 Aug;61(2): 343-8.

122 Lasolle H, Vasiljevic A, Borson-Chazot F, Raverot G. Pasireotide: A potential therapeutic alternative for resistant prolactinoma. Ann Endocrinol (Paris). 2019 Apr;80(2):848.

123 Liu X, Liu Y, Gao J, Feng M, Bao X, Deng K, et al. Combination Treatment with Bromocriptine and Metformin in Patients with Bromocriptine-Resistant Prolactinomas: Pilot Study. World Neurosurg. 2018 Jul;115: 94-8.

124 Wang X, Du Q, Mao Z, Fan X, Hu B, Wang $Z$, et al. Combined treatment with artesunate and bromocriptine has synergistic anticancer effects in pituitary adenoma cell lines. Oncotarget. 2017 Jul;8(28):45874-87.
125 Klionsky DJ, Abdelmohsen K, Abe A, Abedin MJ, Abeliovich H, Acevedo Arozena A, et al. Guidelines for the use and interpretation of assays for monitoring autophagy (3rd edition). Autophagy. 2016;12(1):1-222.

126 Lin SJ, Wu ZR, Cao L, Zhang Y, Leng ZG, Guo YH, et al. Pituitary Tumor Suppression by Combination of Cabergoline and Chloroquine. J Clin Endocrinol Metab. 2017 Oct; 102(10):3692-703.

127 Grossrubatscher E, Veronese S, Ciaramella PD, Pugliese R, Boniardi M, De Carlis L, et al. High expression of dopamine receptor subtype 2 in a large series of neuroendocrine tumors. Cancer Biol Ther. 2008 Dec;7(12): 1970-8.

128 Pivonello C, Rousaki P, Negri M, Sarnataro M, Napolitano M, Marino FZ, et al. Effects of the single and combined treatment with dopamine agonist, somatostatin analog and mTOR inhibitors in a human lung carcinoid cell line: an in vitro study. Endocrine. 2017 Jun;56(3):603-20.
129 Borcherding DC, Tong W, Hugo ER, Barnard DF, Fox S, LaSance K, et al. Expression and therapeutic targeting of dopamine receptor-1 (D1R) in breast cancer. Oncogene. 2016 Jun;35(24):3103-13.

130 Sarkar C, Chakroborty D, Chowdhury UR, Dasgupta PS, Basu S: Dopamine increases the efficacy of anticancer drugs in breast and colon cancer preclinical models. Clin Cancer Res. 2008 Apr 15;14(8):2502-10.

131 Frontini L, Lissoni P, Vaghi M, Perego MS, Pescia S, Ardizzoia A, et al. Enhancement of the efficacy of weekly low-dose taxotere by the long acting anti-prolactinemic drug cabergoline in pretreated metastatic breast cancer. Anticancer Res. 2004 Nov-Dec;24(6): 4223-6.

132 Costa R, Santa-Maria CA, Scholtens DM, Jain S, Flaum L, Gradishar WJ, et al. A pilot study of cabergoline for the treatment of metastatic breast cancer. Breast Cancer Res Treat. 2017 Oct;165(3):585-92. 